\title{
Rethinking Brand Commitment in Internal Branding Models: A Cross-national Validation of a Three-component Model in Germany, China and North America
}

\author{
Christina Ravens-Ocampo \\ University of Aalen
}

There seems to be consensus on the role of brand commitment in internal branding models but overall confusion exists to its affective and cognitive conceptualization. The aim of this research is to add to its clarification over any conceptual confusion. Furthermore, this research attempts to validate whether or not the postulated brand commitment-brand citizenship behavior framework is a universal concept by validating the model among German, Chinese and North American employees of a large automobile manufacturer in Germany.

This research evaluates the dimensionality of brand commitment and brand citizenship behavior and explores cross-country disparity. As the dimensionality of brand commitment and the conceptualization of brand citizenship behavior varies so much as to be unreliable, the author conducted exploratory interviews with senior executives from various organizations listed in the DAX 30 and internal branding consultancies to probe for a holistic IBM model. A semi-structured interview approach was chosen prior to conceptualizing the variance based partial least square and structural equation model (PLS-SEM). The results of the structural relationships are discussed.

Keywords: internal brand management, brand commitment, brand citizenship behavior

\section{INTRODUCTION}

The key factors in delivering the brand promise are employees and the strategic importance of the competitive advantage of an organization (Wentzel, Henkel et al., 2010), and the success of organizations depends on their ability to unlock the potential of their employees when collaborating with external and internal stakeholders (Iyer, Davari et al., 2018; Schmidt and Baumgarth, 2018). Staff understanding and commitment are drivers to brand and business performance, and organizations need to fully ensure that employees understand and internalize these values of their brands to the extent that employees are aligned and committed to enacting those (Thomson, de Chernatony et al., 1999; Harris and de Chernatony, 2001; Preez and Bendixen, 2015). Engaged, empowered and competent employees delivering the brand promise across all brand touchpoints create a sustainable competitive advantage (Gottschalg and Zollo, 2007; Gautam and Bhandari Ghimire, 2017; Mohajan, 2019) through positive, consistent brand experiences, which are a pivotal source of differentiation and more difficult to imitate than functional characteristics (Mosley 2007). Finding and keeping employees both willing and capable to act on behalf of their organization with authority, integrity and competence constitutes a challenge. 
The field of internal brand management understands the role of personnel as the first market of branding initiatives and crucial to the success or failure of an organization. Internal branding attempts to achieve consistency between the external and internal perception of the brand, fosters brand commitment and brand ambassador behavior. It is the "reflection of the values and the realization of the promise of the brand internally and externally (Mahnert and Torres, 2007)".

Within internal brand management (IBM) research, various models capture different conceptualizations of employee's brand ambassador behavior as a desirable outcome of internal branding efforts (Wittke-Kothe, 2001; Burmann and Zeplin, 2005; King and Grace, 2009; Piehler and Burmann, 2009; Ravens, 2014). While frequently new models and their underlying constructs are introduced into the field of IBM models to explore and explain partial aspects of internal branding (Dechawatanapaisal, 2018; Dechawatanapaisal, 2019), surprisingly, there is little attention to holistic models of IBM capturing antecedents to brand citizenship behavior (BCB). There seems to be consensus on brand commitment (Burmann and König, 2011; Piehler, King et al., 2016) but overall confusion to its affective and cognitive conceptualization (Ravens, 2014; Piehler, King et al., 2016), brand identification (Dechawatanapaisal, 2019) as either part of brand commitment (Zeplin, 2006) or a separate dimension (Punjaisri and Wilson, 2007; Piehler, King et al., 2016) of brand understanding (Xiong, King et al., 2013). The aim of this paper is to clarify any conceptual confusion over brand commitment. Furthermore, this research attempts to validate whether or not the brand commitment-brand citizenship behavior framework is a universal concept by validating the model among German, Chinese, and North American employees of a large automobile manufacturer.

\section{LITERATURE REVIEW}

\section{Brand Citizenship Behavior}

Coined by Burmann and Zeplin (2004) and leaning on the concept of organizational citizenship behavior, $\mathrm{BCB}$ is a central construct that subsumes a number of generic brand or industry-dependent employee behaviors. These behaviors enhance the brand identity and are consistent with the brand promise. The concept of BCB does not distinguish between the different roles staff play within an organization and embodies the conviction that all employees across the entire value chain need to embody the identity of the brand through their behavior. The concept of brand supportive behavior has long been recognized (Wittke-Kothe, 2001; Boyd and Sutherland, 2006; Vallaster and de Chernatony, 2006; Henkel, Tomczak et al., 2007), but the authors do not define the construct specifically. Meanwhile, Burmann and Zeplin (2005) introduced brand citizenship behavior with subsequent revisions (Maloney, 2007; Burmann, Zeplin et al., 2009; Ravens, 2014) of its multidimensional conceptualization. While different studies agree on the three-dimensional conceptualizations, the exact definition of these dimensions are not agreed upon. Piehler et al. (2016) proposed brand endorsement (i.e. recommendation of the brand to others), brand development (i.e. proactive advancement of the brand) and brand compliance (acceptance of rules and regulations). Ravens (2014) validated the BCB dimensions of helping behavior, brand development, and brand compliance but could not confirm brand endorsement as a dimension of BCB. This study will conceptualize BCB based on Ravens (2014).

H1: $B C B$ is a three-dimensional construct of helping behavior, brand acceptance, and brand advancement.

\section{Brand Commitment}

Constitutive to the identification of $\mathrm{BCB}$ as a central outcome of internal branding, research indicates brand commitment to be its antecedent (Burmann and Zeplin, 2004; Maloney, 2007). Brand commitment (BC) is inferred directly from relevant organizational commitment (OC) research in organizational behavior and one of the most researched and challenging concepts. Extensive research is devoted to identifying antecedents, modifiers, and consequences of OC insofar that studies have suggested to abandon the term commitment and focus on various concepts instead (Angle and Perry, 1981). High 
levels of commitment are associated with the lack of intent to turnover (Bentein, Vandenberg et al., 2005; Vandenberghe and Bentein, 2009), lack of absenteeism (Iverson and Buttigieg, 1999; Cohen and Kirchmeyer, 2005), job satisfaction (Kirkman and Shapiro, 2001; Markovits, 2007; Kumar and Giri, 2009), customer satisfaction (Caruana and Calleya, 1998; Jaramillo, Mulki et al., 2005), and organizational citizenship behavior (Organ and Ryan, 1995; Meyer, Stanley et al., 2002; Riketta and Landerer, 2005). An adaptation in the form of brand commitment found entry into marketing research. Two conceptually different streams of brand commitment exist. The first conceptualization of brand commitment takes an external, consumer-oriented perspective and the second one pursues an internal perspective. Although implied in various studies (King and Grace, 2008) and vague definitions (Punjaisri, Evanschitzky et al., 2009), internal brand commitment received a theoretically sound conceptualization through Burmann and Zeplin (2004). While other conceptualizations of BC received moderate alterations in extended Burmann and Zeplin models, the core definition of $\mathrm{BC}$ as the psychological attachment of employees to the brand (Piehler, 2011) remained and continued to receive substantial support in later research (Strödter, 2008; Hartmann, 2010,; Esch and Strödter, 2011). While there is consensus on how brand commitment is defined, substantial disagreement over the issues of conceptual taxonomies and brand commitment dimensionality exists. As much as organizational commitment constructs have undergone substantial refinement, ranging from one-dimension to bi-dimension and finally multidimension approaches, brand commitment conceptualizations seem to equally evolve and witness a considerable reevaluation.

Meyer and Allen's conceptualization of organizational commitment as a stabilizing force that gives direction to behaviors with three simultaneous mindsets of affective, continuance, and normative commitment is the most dominant operationalization of OC (Westphal and Gmür, 2009) and transfers the economic (Becker, 1960), psychological (Mowday, Porter et al., 1982), and normative schools (Wiener, 1982) into a model. Affective commitment describes an emotional attachment to the organization such that the individual, strongly committed, identifies with, is involved in, and enjoys membership in the organization. Continuance commitment results from the employee's calculation of the costs, economic and social, associated with leaving the organization. Normative commitment concerns employees' feelings of obligation toward the employer. Despite considerable alternations in 1993, 1997, 2002, and 2006, supportive evidence sustains Meyer and Allen's measure of commitment. As for the apprehension by Burmann and Zeplin raised over Meyer and Allen's conceptual focus on remaining organizational members, their concern seems unwarranted; Meyer at al. (2002) see commitment as distinguishable from transaction-based forms of motivation and from target-relevant attitudes.

Various studies building upon Burmann and Zeplin's initial BC conceptualization struggle with the issue of dimensionality (Zeplin, 2006; Giersch, 2008) with Maloney (2007) and König (2010) struggling to verify the two-dimensional structure of Zeplin's O'Reilly and Chatman's OC-based approach. Piehler (2011) changed his brand commitment conceptualization based initially on O'Reilly and Chatman to a Meyer and Allen-based conceptualization (Piehler, King et al., 2016), but as a one-dimensional, affective brand commitment. Piehler et al. note continuance and normative commitment to entail a strong requirement focus and disregard of those two components based on the notion that organizations require more than continued membership. "That is, understanding an employee's intention to stay is important, but the commitment construct in an IBM setting involves defining the factors that contribute to an employee's brand-related behavior. Normative and continuance forms of commitment are unlikely to lead to pro-brand behavior (...) such forms of commitment may be antithetical to BCB," (Piehler et al., 2016:1578). Furthermore, Piehler, King and Grace argue continuance and normative commitment to be external-oriented dimensions of commitment and as such not suited to predict BCB. However, Meyer and Allen point out that organizational commitment is not limited to affective commitment and its depth, and explanatory power is more suitably assessed using all three components. They further postulate that affective, continuance, and normative commitment are not types of commitment but components. Commitment has both affective and cognitive elements. Consequently, a conceptualization of BC as unidimensional construct may not capture the depth of BC. As a consequence of this broadened approach, continuance brand commitment is an essential element of BC capturing cognitive and affective elements 
in that it depends on employee's individual feeling of "high sacrifice" and "low alternatives" (Wasti, 2002; Jaros, 2007). This study adopts Meyer and Allen's postulated structure of commitment reflecting three mindsets, a target of commitment being the brand, and affective as much as cognitive elements. Affective brand commitment is defined as the employee's attachment to, identification with, and involvement with the brand. Continuance brand commitment results from an employee's calculation of costs, both economic and social, associated with leaving the brand. Finally, normative commitment concerns an employee's feeling of obligation toward the brand.

H2: Brand commitment is a three-component construct of affective, continuance, and normative brand commitment.

H3: Affective brand commitment has a significant, positive effect on $B C B$.

H3a: Affective brand commitment has a significant, positive effect on BCB helping behavior

H3b: Affective brand commitment has a significant, positive effect on $B C B$ brand acceptance

H3c: Affective brand commitment has a significant, positive effect on BCB brand advancement

H4: Continuance brand commitment has a significant, positive effect on BCB.

H4a: Continuance brand commitment has a significant, positive effect on BCB helping behavior

H4b: Continuance brand commitment has a significant, positive effect on BCB brand acceptance

H4c: Continuance brand commitment has a significant, positive effect on BCB brand advancement

H5: Normative brand commitment has a significant, positive effect on $B C B$.

H5a: Normative brand commitment has a significant, positive effect on BCB helping behavior

H5b: Normative brand commitment has a significant, positive effect on BCB brand acceptance

H5c: Normative brand commitment has a significant, positive effect on BCB brand advancement

\section{Method and Data Used}

This research evaluates the dimensionality of brand commitment and brand citizenship behavior and explores cross-country disparity. Since there is a lack of studies addressing these research questions, the nature of this research is exploratory. As the dimensionality of brand commitment and the conceptualization of brand citizenship behavior varies so much and could be unreliable, the author conducted exploratory interviews with senior executives from various organizations listed in the DAX 30, as well as three from internal branding consultancies to probe for a holistic IBM model. A semi-structured interview approach was chosen to gain a deeper understanding of internal brand management problems per se and internationally.

Items reflecting antecedents of brand commitment, brand commitment, and brand citizenship behavior were identified. This paper will focus on the latter two. Cross-cultural research exhibits a higher level of complexity (Boyacigiller and Adler, 1991), demanding additional resources and consideration regarding an emic versus etic approach and conceptual equivalence (Berry, 1969; Herche, Swenson et al., 1996). This research employs an etic approach characterized by taking an outside perspective, where behavioral patterns are related to variations in cultural context. It is generally described by extrinsic concepts and categories to draw cross-cultural comparisons (Davidson, Jaccard et al., 1976). Other 
concerns arise from construct equivalence, as comparability of constructs across cultures and true score calibration may differ (Riordan and Vandenberg, 1994).

The initial survey from 2009 and 2010 contacted 858 employees of a German automobile manufacturer with 244 questionnaires filled out online (Ravens, 2014:141ff.). A second study is currently in progress and the author expects to add to the longitudinal study by the end of fall 2019. The construct measures apply Likert scales, and all scale items are adopted from existing scales with demonstrated reliability and validity. Brand commitment was measured based on an adapted application of Meyer et al.'s (1993) revised six-item scale of the three-component model. The scales were modified to reflect the internal branding context of the research. Brand citizenship behavior was measured by applying Zeplin's (2006) scale with the exception of brand acceptance, which is measured by applying an adjusted Graham's (1991) scale.

\section{Brand Commitment}

Brand commitment is a new concept, which is an attitude-based antecedent of brand citizenship behavior; the scientific community resorts to few theoretical and empirical analyses. At the same time, research draws from extensive organizational commitment analyses, both theoretically and empirically. This research models brand commitment and brand citizenship behavior as a second-order type II model (Jarvis, Mackenzie et al., 2003) with a reflective measurement specification and the direction of causality moving from the construct to the indicators on the first level, and the formative measurement specification with the direction of causality moving from the items to the construct on the second level.

Exploratory factor analysis was used to substantiate the proposed three-component conceptualization of brand commitment with six indicators per component. The extraction method applied is a principal component analysis with a rotation converged in 5 iterations (varimax with Kaiser normalization). An evaluation of the indicator's reliability shows affective brand commitment to be a unidimensional construct after the elimination of one indicator showing a loading below the elimination value of 0.4 . The loadings, otherwise, substantiate adequate reliability. All t-values are significant. The average variance extracted, and composite reliability values are above their respective thresholds of 0.5 and 0.7 with an eigenvalue of 2.837 and Stone-Geisser test of 0.508 substantiating the construct's reliability. Continuance and normative brand commitment behavior's construct reliability was equally substantiated by applying the same methodology.

Discriminant validity of all three components is given based on meeting the Fornell and Larcker criterion. Evaluation across the entire sample substantiates brand commitment to be a three-component construct consisting of affective, continuance, and normative brand commitment. Furthermore, the measurement model evaluation of affective, continuance, and normative brand commitment meets the indicator's and construct's evaluation criteria for the German, Chinese, and North American settings after the elimination of one $\mathrm{AC}$ item, two $\mathrm{CC}$ and $\mathrm{NC}$ items. All other indicator and construct evaluation criteria are met and substantiate the universalism of affective, continuance, and normative brand commitment across all subsamples (see Table 1).

\section{Brand Citizenship Behavior}

Given the conceptual differences found between Maloney (2007) and Zeplin (2006) and the exploratory nature of the research, both concepts were tested with the intent to verify which of the two three-dimensional conceptualizations of $\mathrm{BCB}$ can be substantiated. Similar to brand commitment, there are a limited number of theoretical and empirical analyses of brand citizenship behavior, let alone tested cross-culturally.

Brand citizenship behavior is a type II second-order model. Due to the internal brand management focus of this research, Zeplin's scales are adopted with the exception of three Graham (1991) items for brand acceptance. As with $\mathrm{BC}$, an exploratory factor analysis was conducted. The rotation matrix substantiates a three-dimensional structure of $\mathrm{BCB}$ across the total sample, but can neither confirm Maloney's nor Zeplin's conceptualization but a mix of both. This survey reconfirmed helping behavior as a separate dimension. The items loading on Zeplin's brand endorsement, which were renamed brand 
missionary in Maloney's study, show two items loading on helping behavior and three on brand acceptance. Construct reliability is confirmed for each dimension, with AVE and composite reliability values exceeding their respective mark. In a second step, the construct reliability is confirmed for each subsample, thereby substantiating the reliability of the model.

The brand commitment and brand citizenship behavior measurement models are analyzed further through a series of tests following the procedure of Wold's hierarchical component method examining nomological validity, indicator relevance, and multicollinearity (VIF). Both measurement models met the required evaluation criteria.

Variance-based partial least square and structural equation modelling (PLS-SEM) was chosen due to its small sample size and due to the nature of $\mathrm{BCB}$ and $\mathrm{BC}$ being second-order type II models. The results of the structural relationships are shown in Figure 1. PLS-SEM uses two-stage factor approaches to analyze second-order constructs (Ringle, 2004). The results of the structural relationship are shown in Figure 1.

Evaluation of the relationship between brand commitment and brand citizenship behavior across the three groups identifies substantial differences (see Figure 1- lower part). Coefficients of determination, $\mathrm{R}^{2}$, vary. Across all evaluations, the German $\mathrm{R}^{2}$ is lower $(0.114)$ than in the North American $(0.388)$ and Chinese samples (0.466). Affective and normative $\mathrm{BC}$ have positive relationships with helping behavior, brand acceptance, and brand advancement, but their relevance differs across regions and the relevance of continuance $\mathrm{BC}$ absent in some (refer to Figure 1).

The relationship between affective, continuance, and normative $\mathrm{BC}$ displays a pattern across evaluations conducted on the entire sample and on the three separate groups. Affective and normative brand commitment are the central drivers of brand citizenship behavior. Interestingly, results of the $\mathrm{BC}$ $\mathrm{BCB}$ behavior constructs among the Chinese and the North American sample deviate from the results obtained across the total sample. Continuance BC shows a positive relationship with all three BCB dimensions among the Chinese group and with brand acceptance among the North American group but none with the German sample. In conclusion, the Chinese sample displays a different pattern from the German and North American samples in that continuance brand commitment and normative brand commitment are the central predictors of BCB. All hypotheses are confirmed.

\section{DISCUSSION}

This study extends Burmann and Zeplin's (2004) model, as well as Maloney's (2007), König's (2011) and Piehler's (2011) extension of the internal brand management model. It was tested in Germany, China, and North America.

The findings of this research contribute to an understanding of brand commitment and brand citizenship by adding to the component of affective brand commitment, continuance, and normative brand commitment based on Meyer and Allen's notion that commitment exhibits both affective and cognitive elements. This research provides interesting insights into the interdependencies of the componentdimension relationships. Affective and normative brand commitment share a much stronger relationship with brand citizenship behavior than continuance brand commitment. Continuance brand commitment is, however, an important predictor of brand citizenship behavior in China and, to a lesser degree, in North America. While helping behavior is a dominant component of brand citizenship behavior across all three subsamples, the importance of brand advancement and brand acceptance varies across the groups.

Secondly, the research shows the brand commitment and brand citizenship behavior conceptualization as universal and therefore valid and reliable across Germany, China, and North America. The paper aimed to clarify conceptual confusion and could establish that brand commitment and brand citizenship behavior consist of three distinct components. Furthermore, this research validated Meyer et al.'s understanding of commitment to include continuance and normative commitment. Brand commitment is not limited to affective commitment but a much broader construct than suggested in various studies (Piehler, King et al., 2016). 
The scope of this paper is limited to the $\mathrm{BC}-\mathrm{BCB}$ relationship. A central finding of this study establishes that internal branding strategies need to allow for adaptation to relevant local contexts. While internal branding is a universal concept, the application needs to integrate a local perspective. Future research and a currently ongoing study will analyze the relevance of the various brand commitment instruments to brand commitment. As much as organizations adjust their marketing efforts to local customer requirements, organizations need to develop a better understanding of all the options available to increase employees' brand-aligned behavior.

\section{LIMITATIONS AND FUTURE RESEARCH}

This study shows the following limitations: For one, cross-cultural differences regarding the antecedents of brand commitment are postulated but exceed the scope of this paper. Secondly, the sample size is relatively small and taken from the same company, which may influence the representative nature of the study. Future research will therefore be directed toward validating the same model across a larger sample and from different industries within Germany, China, and North America. The two latter subsamples were relatively small and more international groups should be added to future studies. The first wave of these internal branding studies tends to focus on quantitative cross-sectional analyses. A longitudinal analysis of internal branding would add to the research significantly. Furthermore, the study uses PLS-SEM over covariance-based structural equation modeling due to the small size of the sample. However, PLS has been criticized for being statistically less precise, criticized for overstating a model, and is often referred to as "soft modelling". A larger sample would allow for more conservative quantitative tools such as LISREL.

TABLE 1

SELECTED RESULTS

\begin{tabular}{|c|c|c|c|c|c|c|c|}
\hline \multicolumn{8}{|c|}{ Affective Brand Commitment } \\
\hline \multirow[b]{2}{*}{ Region } & \multirow[b]{2}{*}{ Indicator } & \multicolumn{2}{|c|}{ Indicator Evaluation Criteria } & \multicolumn{4}{|c|}{ Construct Evaluation Criteria } \\
\hline & & $\begin{array}{l}\text { Loading } \\
>0.7(>0.4)\end{array}$ & $\begin{array}{l}\text { t-value } \\
>1.96 I \\
>1.64\end{array}$ & $\begin{array}{l}\text { AVE } \\
>0.5\end{array}$ & $\begin{array}{l}\text { Composite } \\
\text { Reliability } \\
>0.7\end{array}$ & $\begin{array}{l}\text { Eigen- } \\
\text { values }>1\end{array}$ & $\begin{array}{l}\text { Stone-Geisser } \\
Q^{2}>0.1\end{array}$ \\
\hline \multirow[t]{5}{*}{ Germany } & $\mathrm{BC} A \mathrm{AC} 1$ & 0.663 & 12.808 & \multirow{5}{*}{0.505} & \multirow{5}{*}{0.714} & \multirow{5}{*}{2.557} & \multirow{5}{*}{0.525} \\
\hline & $\mathrm{BC} \_\mathrm{AC} \_3$ & 0.536 & 5.903 & & & & \\
\hline & $\mathrm{BC} A C 4$ & 0.796 & 15.700 & & & & \\
\hline & $\mathrm{BC}$ AC_5 & 0.821 & 43.520 & & & & \\
\hline & $B C A C \quad 6$ & 0.701 & 10.051 & & & & \\
\hline \multirow[t]{5}{*}{ China } & $\mathrm{BC}_{2} \mathrm{AC}_{-} 1$ & 0.750 & 19.515 & \multirow{5}{*}{0.590} & \multirow{5}{*}{0.743} & \multirow{5}{*}{6.277} & \multirow{5}{*}{0.589} \\
\hline & $\mathrm{BC} A \mathrm{AC} 3$ & 0.817 & 12.979 & & & & \\
\hline & $\mathrm{BC} \_\mathrm{AC} \_4$ & 0.772 & 11.999 & & & & \\
\hline & $\mathrm{BC} A C 5$ & 0.794 & 35.526 & & & & \\
\hline & $B C A C \_6$ & 0.702 & 9.067 & & & & \\
\hline \multirow[t]{5}{*}{ North America } & $\mathrm{BC}_{-} \mathrm{AC}_{-} 1$ & 0.759 & 18.986 & \multirow{5}{*}{0.551} & \multirow{5}{*}{0.789} & \multirow{5}{*}{3.836} & \multirow{5}{*}{0.589} \\
\hline & BC AC 3 & 0.898 & 11.578 & & & & \\
\hline & BC_AC_4 & 0.802 & 11.606 & & & & \\
\hline & $\mathrm{BC} A C 5$ & 0.781 & 30.565 & & & & \\
\hline & $\mathrm{BC} \mathrm{AC}_{6} 6$ & 0.346 & 8.176 & & & & \\
\hline
\end{tabular}




\begin{tabular}{|c|c|c|c|c|c|c|c|}
\hline \multicolumn{8}{|c|}{ Continuance Brand Commitment } \\
\hline \multirow[b]{2}{*}{ Region } & \multirow[b]{2}{*}{ Indicator } & \multicolumn{2}{|c|}{ Indicator Evaluation Criteria } & \multicolumn{4}{|c|}{ Construct Evaluation Criteria } \\
\hline & & $\begin{array}{l}\text { Loading } \\
>0.7(>0.4)\end{array}$ & $\begin{array}{l}\text { t-value } \\
>1.96 I \\
>1.64\end{array}$ & $\begin{array}{l}\text { AVE } \\
>0.5\end{array}$ & $\begin{array}{l}\text { Composite } \\
\text { Reliability } \\
>0.7\end{array}$ & $\begin{array}{l}\text { Eigen- } \\
\text { values }>1\end{array}$ & $\begin{array}{l}\text { Stone-Geisser } \\
Q^{2}>0.1\end{array}$ \\
\hline \multirow[t]{4}{*}{ Germany } & $\mathrm{BC}$ CC 1 & 0.785 & 24.150 & \multirow{4}{*}{0.508} & \multirow{4}{*}{0.798} & \multirow{4}{*}{2.035} & \multirow{4}{*}{0.443} \\
\hline & $\mathrm{BC}$ CC_2 & 0.802 & 18.939 & & & & \\
\hline & BC_CC_3 & 0.756 & 16.001 & & & & \\
\hline & $\mathrm{BC} \_\mathrm{CC} 6$ & 0.447 & 4.803 & & & & \\
\hline \multirow[t]{4}{*}{ China } & BC_CC_1 & 0.663 & 7.872 & \multirow{4}{*}{0.508} & \multirow{4}{*}{0.792} & \multirow{4}{*}{4.069} & \multirow{4}{*}{0.513} \\
\hline & $\mathrm{BC} C \mathrm{C} 2$ & 0.367 & 2.909 & & & & \\
\hline & BC_CC_3 & 0.883 & 50.296 & & & & \\
\hline & $\mathrm{BC} \_\mathrm{CC} 6$ & 0.824 & 21.854 & & & & \\
\hline \multirow[t]{4}{*}{ North America } & BC_CC_1 & 0.477 & 38.343 & \multirow{4}{*}{0.506} & \multirow{4}{*}{0.797} & \multirow{4}{*}{2.087} & \multirow{4}{*}{0.614} \\
\hline & $\mathrm{BC} C \mathrm{CC} 2$ & 0.858 & 27.891 & & & & \\
\hline & $\mathrm{BC} \_\mathrm{CC} \_3$ & 0.644 & 31.061 & & & & \\
\hline & BC_CC_6 & 0.804 & 7.907 & & & & \\
\hline \multicolumn{8}{|c|}{ Normative Brand Commitment } \\
\hline \multirow[b]{2}{*}{ Region } & \multirow[b]{2}{*}{ Indicator } & \multicolumn{2}{|c|}{ Indicator Evaluation Criteria } & \multicolumn{4}{|c|}{ Construct Evaluation Criteria } \\
\hline & & $\begin{array}{l}\text { Loading } \\
>0.7(>0.4)\end{array}$ & $\begin{array}{l}\text { t-value } \\
>1.96 I \\
>1.64\end{array}$ & $\begin{array}{l}\text { AVE } \\
>0.5\end{array}$ & $\begin{array}{l}\text { Composite } \\
\text { Reliability } \\
>0.7\end{array}$ & $\begin{array}{l}\text { Eigen- } \\
\text { values }>1\end{array}$ & $\begin{array}{l}\text { Stone-Geisser } \\
Q^{2}>0.1\end{array}$ \\
\hline \multirow[t]{4}{*}{ Germany } & BC_NC_1 & 0.545 & 6.731 & \multirow{4}{*}{0.607} & \multirow{4}{*}{0.857} & \multirow{4}{*}{2.138} & \multirow{4}{*}{0.612} \\
\hline & $\mathrm{BC} \_\mathrm{NC} \_3$ & 0.859 & 40.783 & & & & \\
\hline & $\mathrm{BC} \_\mathrm{NC} 4$ & 0.882 & 54.294 & & & & \\
\hline & BC_NC_5 & 0.784 & 22.419 & & & & \\
\hline China & $\mathrm{BC} N \mathrm{NC} 1$ & 0.858 & 37.527 & & & & \\
\hline & $\mathrm{BC} N \mathrm{NC} 3$ & 0.870 & 29.910 & & & & \\
\hline & $\mathrm{BC} N \mathrm{NC} 4$ & 0.843 & 32.767 & 0.656 & 0.883 & 3.166 & 0.614 \\
\hline & BC_NC_5 & 0.647 & 7.823 & & & & \\
\hline North America & BC NC 1 & 0.593 & 7.383 & & & & \\
\hline & BC_NC_3 & 0.739 & 2.731 & & & & \\
\hline & $\mathrm{BC} \mathrm{NC} 4$ & 0.887 & 51.441 & 0.554 & 0.831 & $2.1 / 2$ & 0.513 \\
\hline & BC_NC_5 & 0.787 & 20.386 & & & & \\
\hline
\end{tabular}

TABLE 2

SELECTED RESULTS

\begin{tabular}{|c|c|c|c|c|c|c|c|}
\hline \multirow[b]{3}{*}{ 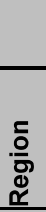 } & \multicolumn{7}{|c|}{ Helping Behavior across the three subsamples } \\
\hline & \multirow[b]{2}{*}{ Indicator } & \multicolumn{2}{|c|}{ Indicator Evaluation Criteria } & \multicolumn{4}{|c|}{ Construct Evaluation Criteria } \\
\hline & & $\begin{array}{l}\text { Loading } \\
>0.7(>0.4)\end{array}$ & $\begin{array}{l}\mathrm{t} \text {-value } \\
>1.96 \mathrm{I} \\
>1.64 \\
\end{array}$ & $\begin{array}{l}\text { AVE } \\
>0.5\end{array}$ & $\begin{array}{l}\text { Composite } \\
\text { Reliability } \\
>0.7\end{array}$ & $\begin{array}{l}\text { Eigenvalues } \\
>1\end{array}$ & $\begin{array}{l}\text { Stone- } \\
\text { Geisser } \\
Q^{2}>0.1 \\
\end{array}$ \\
\hline \multirow{8}{*}{ 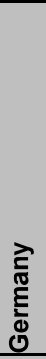 } & BCB_BC_1 & 0.737 & 14.898 & \multirow{8}{*}{0.601} & \multirow{8}{*}{0.923} & \multirow{8}{*}{4.812} & \multirow{8}{*}{0.585} \\
\hline & BCB_HB_2 & 0.827 & 25.508 & & & & \\
\hline & BCB_HB_3 & 0.873 & 50.028 & & & & \\
\hline & BCB_HB_4 & 0.870 & 48.403 & & & & \\
\hline & BCB_HB_5 & 0.745 & 20.245 & & & & \\
\hline & BCB_BM_BE_1 & 0.762 & 20.068 & & & & \\
\hline & BCB_BM_BE_2 & 0.676 & 11.514 & & & & \\
\hline & BCB_BACC_5 & 0.685 & 13.394 & & & & \\
\hline \multirow{6}{*}{ : } & BCB_BC_1 & 0.873 & 72.659 & \multirow{6}{*}{0.672} & \multirow{6}{*}{0.941} & \multirow{6}{*}{5.404} & \multirow{6}{*}{0.649} \\
\hline & BCB_HB_2 & 0.893 & 71.047 & & & & \\
\hline & BCB_HB_3 & 0.886 & 39.465 & & & & \\
\hline & BCB_HB_4 & 0.849 & 21.534 & & & & \\
\hline & BCB_HB_5 & 0.730 & 17.016 & & & & \\
\hline & BCB_BM_BE_1 & 0.856 & 29.456 & & & & \\
\hline
\end{tabular}

56 Journal of Marketing Development and Competitiveness Vol. 14(2) 2020 


\begin{tabular}{|c|c|c|c|c|c|c|c|}
\hline \multirow{5}{*}{ 흥 } & \multicolumn{7}{|c|}{ Helping Behavior across the three subsamples } \\
\hline & \multirow[b]{2}{*}{ Indicator } & \multicolumn{2}{|c|}{ Indicator Evaluation Criteria } & \multicolumn{4}{|c|}{ Construct Evaluation Criteria } \\
\hline & & $\begin{array}{l}\text { Loading } \\
>0.7(>0.4)\end{array}$ & $\begin{array}{l}\text { t-value } \\
>1.96 I \\
>1.64 \\
\end{array}$ & $\begin{array}{l}\text { AVE } \\
>0.5\end{array}$ & $\begin{array}{l}\text { Composite } \\
\text { Reliability } \\
>0.7\end{array}$ & $\begin{array}{l}\text { Eigenvalues } \\
>1\end{array}$ & $\begin{array}{l}\text { Stone- } \\
\text { Geisser } \\
Q^{2}>0.1 \\
\end{array}$ \\
\hline & BCB_BM_BE_2 & 0.874 & 63.229 & & & & \\
\hline & BCB_BACC_5 & 0.530 & 7.886 & & & & \\
\hline \multirow{8}{*}{ 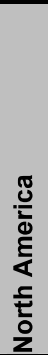 } & BCB_BC_1 & 0.821 & 14.456 & \multirow{8}{*}{0.739} & \multirow{8}{*}{0.957} & \multirow{8}{*}{5.916} & \multirow{8}{*}{0.585} \\
\hline & BCB_HB_2 & 0.844 & 26.945 & & & & \\
\hline & BCB_HB_3 & 0.914 & 48.110 & & & & \\
\hline & BCB_HB_4 & 0.863 & 44.933 & & & & \\
\hline & BCB_HB_5 & 0.811 & 18.711 & & & & \\
\hline & BCB_BM_BE_1 & 0.842 & 19.456 & & & & \\
\hline & BCB_BM_BE_2 & 0.919 & 12.218 & & & & \\
\hline & BCB_BACC_5 & 0.860 & 12.698 & & & & \\
\hline
\end{tabular}

\begin{tabular}{|c|c|c|c|c|c|c|c|}
\hline \multirow[b]{3}{*}{ ס } & \multicolumn{7}{|c|}{ Brand acceptance across the three subsamples } \\
\hline & \multirow[b]{2}{*}{ Indicator } & \multicolumn{2}{|c|}{ Indicator Evaluation Criteria } & \multicolumn{4}{|c|}{ Construct Evaluation Criteria } \\
\hline & & $\begin{array}{l}\text { Loading } \\
>0.7(>0.4)\end{array}$ & $\begin{array}{l}\text { t-value } \\
>1.96 I \\
>1.64\end{array}$ & $\begin{array}{l}\text { AVE } \\
>0.5\end{array}$ & $\begin{array}{l}\text { Composite Re- } \\
\text { liability } \\
>0.7\end{array}$ & $\begin{array}{l}\text { Eigenvalues } \\
>1\end{array}$ & $\begin{array}{l}\text { Stone- } \\
\text { Geisser } \\
Q^{2}>0.1\end{array}$ \\
\hline \multirow{6}{*}{ 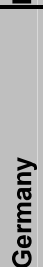 } & BCB_BM_BE_3 & 0.570 & 7.959 & \multirow{6}{*}{0.569} & \multirow{6}{*}{0.886} & \multirow{6}{*}{4.488} & \multirow{6}{*}{0.417} \\
\hline & BCB_BM_M_1 & 0.720 & 13.552 & & & & \\
\hline & BCB_BM_M_2 & 0.785 & 22.580 & & & & \\
\hline & BCB_ACC_1 & 0.849 & 22.586 & & & & \\
\hline & BCB_ACC_2 & 0.847 & 44.221 & & & & \\
\hline & BCB_ACC_3 & 0.719 & 19.405 & & & & \\
\hline \multirow{6}{*}{ 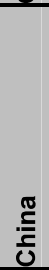 } & BCB_BM_BE_3 & 0.661 & 12.851 & \multirow{6}{*}{0.581} & \multirow{6}{*}{0.891} & \multirow{6}{*}{4.589} & \multirow{6}{*}{0.457} \\
\hline & BCB_BM_M_1 & 0.662 & 11.426 & & & & \\
\hline & BCB_BM_M_2 & 0.768 & 17.481 & & & & \\
\hline & BCB_ACC_1 & 0.924 & 92.642 & & & & \\
\hline & BCB_ACC_2 & 0.857 & 48.228 & & & & \\
\hline & BCB_ACC_3 & 0.655 & 18.145 & & & & \\
\hline \multirow{6}{*}{ 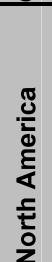 } & BCB_BM_BE_3 & 0.444 & 8.554 & \multirow{6}{*}{0.570} & \multirow{6}{*}{0.884} & \multirow{6}{*}{3.427} & \multirow{6}{*}{0.550} \\
\hline & BCB_BM_M_1 & 0.821 & 14.096 & & & & \\
\hline & BCB_BM_M_2 & 0.868 & 23.470 & & & & \\
\hline & BCB_ACC_1 & 0.831 & 33.455 & & & & \\
\hline & BCB_ACC_2 & 0.829 & 42.847 & & & & \\
\hline & BCB_ACC_3 & 0.645 & 18.873 & & & & \\
\hline
\end{tabular}




\begin{tabular}{|c|c|c|c|c|c|c|c|}
\hline \multirow[b]{3}{*}{$\frac{5}{\frac{0}{8}}$} & \multicolumn{7}{|c|}{ Brand advancement across the three subsamples } \\
\hline & \multirow[b]{2}{*}{ Indicator } & \multicolumn{2}{|c|}{ Indicator Evaluation Criteria } & \multicolumn{4}{|c|}{ Construct Evaluation Criteria } \\
\hline & & $\begin{array}{l}\text { Loading } \\
>0.7(>0.4)\end{array}$ & $\begin{array}{l}\text { t-value } \\
>1.96 I \\
>1.64\end{array}$ & $\begin{array}{l}\text { AVE } \\
>0.5\end{array}$ & $\begin{array}{l}\text { Composite } \\
\text { Reliability } \\
>0.7\end{array}$ & $\begin{array}{l}\text { Eigen- } \\
\text { values } \\
>1\end{array}$ & $\begin{array}{l}\text { Stone-Geisser } \\
Q^{2}>0.1\end{array}$ \\
\hline \multirow{6}{*}{ 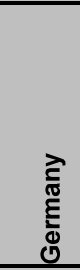 } & BCB_ADV_1 & 0.732 & 21.943 & \multirow{6}{*}{0.565} & \multirow{6}{*}{0.885} & \multirow{6}{*}{3.407} & \multirow{6}{*}{0.565} \\
\hline & BCB_ADV_2 & 0.825 & 24.990 & & & & \\
\hline & BCB_ADV_3 & 0.687 & 9.147 & & & & \\
\hline & BCB_ADV_4 & 0.848 & 33.535 & & & & \\
\hline & BCB_ADV_5 & 0.722 & 7.996 & & & & \\
\hline & BCB_ACC_4 & 0.679 & 17.627 & & & & \\
\hline \multirow{6}{*}{ : } & BCB_ADV_1 & 0.904 & 68.864 & \multirow{6}{*}{0.675} & \multirow{6}{*}{0.924} & \multirow{6}{*}{4.059} & \multirow{6}{*}{0.675} \\
\hline & BCB_ADV_2 & 0.926 & 83.447 & & & & \\
\hline & BCB_ADV_3 & 0.859 & 42.212 & & & & \\
\hline & BCB_ADV_4 & 0.875 & 48.381 & & & & \\
\hline & BCB_ADV_5 & 0.727 & 16.664 & & & & \\
\hline & BCB_ACC_4 & 0.586 & 9.401 & & & & \\
\hline \multirow{6}{*}{ 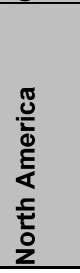 } & BCB_ADV_1 & 0.879 & 22.539 & \multirow{6}{*}{0.656} & \multirow{6}{*}{0.912} & \multirow{6}{*}{3.942} & \multirow{6}{*}{0.555} \\
\hline & BCB_ADV_2 & 0.656 & 26.441 & & & & \\
\hline & BCB_ADV_3 & 0.914 & 9.921 & & & & \\
\hline & BCB_ADV_4 & 0.791 & 34.219 & & & & \\
\hline & BCB_ADV_5 & 0.812 & 8.075 & & & & \\
\hline & BCB_ACC_4 & 0.787 & 17.806 & & & & \\
\hline
\end{tabular}


FIGURE 1

PATH COEFFICIENTS BC - BCB RELATIONSHIP ACROSS TOTAL SAMPLES AND SUBSAMPLES

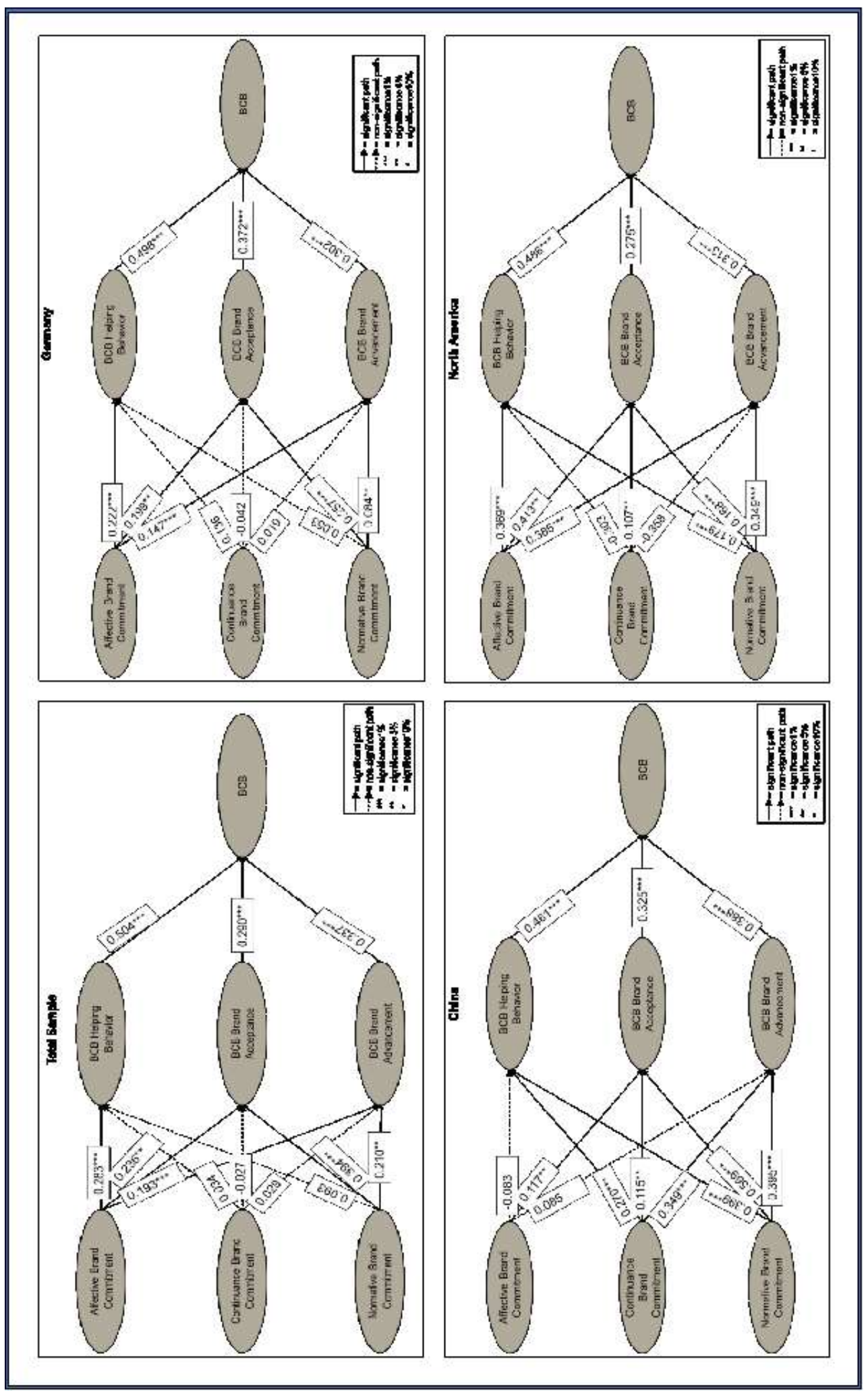

Journal of Marketing Development and Competitiveness Vol. 14(2) 2020 


\section{REFERENCES}

Angle, H. L., \& Perry, J. L. (1981). An empirical assessment of organizational commitment and organizational effectiveness. Administrative Science Quarterly, 26(1), 1-14.

Becker, H. S. (1960). Notes on the concept of commitment. American Journal of Sociology, 66(1), 32-40.

Bentein, K., Vandenberg, R., Vandenberghe, C., \& Stinglhamber, F. (2005). The role of change in the relationship between commitment and turnover: A latent growth modeling approach. Journal of Applied Psychology, 90(3), 468-482.

Berry, J. W. (1969). On cross-cultural comparability. International Journal of Psychology, 4(2), 119-128.

Boyacigiller, N., \& Adler, N. J. (1991). The parochial dinosaur: Organizational science in a global context. Academy of Management Review, 16(2), 262-290.

Boyd, G., \& Sutherland, M. (2006). Obtaining employee commitment to living the brand of the organisation. South African Journal of Business Management, 37(1), 9-20.

Burmann, C., \& König, V. (2011). Does Internal Brand Management really drive Brand Commitment in Shared-Service Call Centers? Journal of Brand Management, 18(6), 374-393.

Burmann, C., \& Zeplin, S. (2004). Innengerichtetes identitätsbasiertes Markenmanagement: State-of-theart und Forschungsbedarf. LiM Arbeitspapier 07, Lehrstuhl für innovatives Markenmanagement, Universität Bremen.

Burmann, C., \& Zeplin, S. (2005). Building brand commitment: A behavioural approach to internal brand management. Journal of Brand Management, 12(4), 279-300.

Burmann, C., Zeplin, S., \& Riley, N. (2009). Key determinants of internal brand management success: An exploratory empirical analysis. Journal of Brand Management, 16(4), 264-284.

Caruana, A., \& Calleya, P. (1998). The effect of internal marketing on organisational commitment among retail bank managers. International Journal of Bank Marketing, 16(3), 108-116.

Cohen, A., \& Kirchmeyer, C. (2005). A cross-cultural study of the work/nonwork interface among Israeli Nurses. Applied Psychology: An International Review, 54(4), 537-567.

Davidson, A. R., Jaccard, J. J., Triandis, H. C., Morales, M. L., \& Diaz-Guerrero, R. (1976). Crosscultural model testing: Toward a solution of the etic-emic dilemma. International Journal of Psychology, 11(1), 1-13.

Dechawatanapaisal, D. (2018). Employee retention: the effects of internal branding and brand attitudes in sales organizations. Personnel Review, 47(3), 675-693.

Dechawatanapaisal, D. (2019). Internal branding and employees' brand outcomes: Do generational differences and organizational tenure matter? Industrial \& Commercial Training, 51(4), 209-227.

Esch, F-R., \& Strödter, K. (2011). Aufbau des Markencommitment in Abhängigkeit des MitarbeiterMarken-Fits. Behavioral Branding. T. Tomczak, F.-R. Esch, J. Kernstock and A. Herrmann. Wiesbaden, Gabler Verlag: 141-160.

Gautam, D. K., \& Bhandari Ghimire, S. (2017). Psychological empowerment of employees for competitive advantages. International Journal of Law \& Management, 59(4), 466-488.

Giersch, J. (2008). Corporate Brand Management international tätiger Unternehmen. Wiesbaden, Gabler.

Gottschalg, O., \& Zollo, M. (2007). Interest alignment and competitive advantage. Academy of Management Review, 32(2), 418-437.

Harris, F., \& de Chernatony, L. (2001). Corporate branding and corporate brand performance. European Journal of Marketing, 35(3/4), 441-456.

Hartmann, K. (2010). Wirkung der Markenwahrnehmung auf das Markencommitment von Mitarbeitern. Hamburg, Verlag Dr. Kovac.

Henkel, S., Tomczak, T., Heitmann, M., \& Herrmann, A. (2007). Managing brand consistent employee behaviour: Relevance and managerial control of behavioural branding. Journal of Product \& Brand Management, 16(5), 310-320.

Herche, J., Swenson, M. J., \& Verbeke, W. (1996). Personal selling constructs and measures: Emic versus etic approaches to cross-national research. European Journal of Marketing, 30(7), 83-97.

60 Journal of Marketing Development and Competitiveness Vol. 14(2) 2020 
Iverson, R. D., \& Buttigieg, D. M. (1999). Affective, normative and continuance commitment: Can the 'right kind' of commitment be managed? Journal of Management Studies, 36(3), 307-333.

Iyer, P., Davari, A., \& Paswan, A. (2018). Determinants of brand performance: the role of internal branding. Journal of Brand Management, 25(3), 202-216.

Jaramillo, F., Mulki, J. P., \& Marshall, G. W. (2005). A meta-analysis of the relationship between organizational commitment and salesperson job performance: 25 years of research. Journal of Business Research, 58(6), 705-714.

Jaros, S. (2007). Meyer and Allen model of organizational commitment: Measurement issues. ICFAI Journal of Organizational Behavior, 6(4), 7-25.

Jarvis, C. B., Mackenzie, S. B., Podsakoff, P. M., Mick, D. G., \& Bearden, W. O. (2003). A critical review of construct indicators and measurement model misspecification in marketing and consumer research. Journal of Consumer Research, 30(2), 199-218.

King, C., \& Grace, D. (2008). Internal branding: Exploring the employee's perspective. Journal of Brand Management, 15(5), 358-372.

King, C., \& Grace, D. (2009). Employee based brand equity: A third perspective. Services Marketing Quarterly, 30(2), 122-147.

Kirkman, B. L., \& Shapiro, D. L. (2001). The impact of cultural values on job satisfaction and organizational commitment in self-managing work teams: The mediating role of employee resistance. Academy of Management Journal, 44(3), 557-569.

Kumar, B. P., \& Giri, V. N. (2009). Effect of age and experience on job satisfaction and organizational commitment. ICFAI Journal of Organizational Behavior, 8(1), 28-36.

Mahnert, K. E., \& Torres, A. M. (2007). The brand inside: The factors of failure and success in internal branding. Irish Marketing Review, 19(1/2), 54-63.

Maloney, P. (2007). Absatzmittlergerichtetes, identitätsbasiertes Markenmanagement. Wiesbaden, Deutscher Universitäts-Verlag.

Markovits, Y. (2007). Organizational commitment profiles and job satisfaction among Greek private and public sector employees. International Journal of Cross Cultural Management, 7(1), 77-99.

Meyer, J. P., Stanley, D. J., Herscovitch, L., \& Topolnytsky, L. (2002). Affective, continuance, and normative commitment to the organization: A meta-analysis of antecedents, correlates, and consequences. Journal of Vocational Behavior, 61(1), 20-52.

Mohajan, H. K. (2019). Knowledge Sharing among Employees in Organizations. Journal of Economic Development, Environment \& People, 8(1), 52-61.

Mosley, R. W. (2007). Customer experience, organisational culture and the employer brand. Journal of Brand Management, 15(2), 123-134.

Mowday, R. T., Porter, L. W., \& Steers, R. M. (1982). Employee-organizational linkage. New York, Academic Press.

Organ, D. W., \& Ryan, K. (1995). A meta-analytic review of attitudinal and dispositional predictors of organizational citizenship behavior. Personnel Psychology, 48(4), 775-802.

Piehler, R. (2011). Interne Markenführung: Theoretisches Konzept und fallstudienbasierte Evidenz. Wiesbaden, Gabler Verlag.

Piehler, R., \& Burmann, C. (2009, April 6-7). Antecedents and consequences of brand commitment in the context of internal brand management. 5th Thought Leaders International Conference on Brand Management: Athens, Greece.

Piehler, R., King, C., Burmann, C., \& Xiong, L. (2016). The importance of employee brand understanding, brand identification, and brand commitment in realizing brand citizenship behaviour. European Journal of Marketing, 50(9/10), 1575-1601.

Preez, R. D., \& Bendixen, M. T. (2015). The impact of internal brand management on employee job satisfaction, brand commitment and intention to stay. International Journal of Bank Marketing, 33(1), 78-91.

Punjaisri, K., Evanschitzky, H., \& Wilson, A. (2009). Internal branding: An enabler of employees' brandsupporting behaviours. Journal of Service Management, 20(2), 209-226. 
Punjaisri, K., \& Wilson, A. (2007). The role of internal branding in the delivery of employee brand promise. Journal of Brand Management, 15(1), 57-70.

Ravens, C. (2014). Internal Brand Management in an International Context. Wiesbaden, Springer Gabler.

Riketta, M., \& Landerer, A. (2005). Does perceived threat to organizational status moderate the relation between organizational commitment and work behavior? International Journal of Management, 22(2), 193-200.

Ringle, C. M. (2004). Gütemaß für den Partial-Least-Squares-Ansatz zur Bestimmung von Kausalmodellen. Hamburg: Univ. Hamburg, Institut für Industriebetriebslehre und Organisation, Arbeitsbereich Industrielles Management.

Riordan, C. M., \& Vandenberg, R. J. (1994). A central question in cross-cultural research: Do employees of different cultures interpret work-related measures in an equivalent manner? Journal of Management, 20(3), 643-671.

Schmidt, H. J., \& Baumgarth, C. (2018). Strengthening internal brand equity with brand ambassador programs: development and testing of a success factor model. Journal of Brand Management, 25(3), 250-265.

Strödter, K. (2008). Markencommitment bei Mitarbeitern. Berlin, Logos Berlin.

Thomson, K., de Chernatony, L., Arganbright, L., \& Khan, S. (1999). The buy-in benchmark: How staff understanding and commitment impact brand and business performance. Journal of Marketing Management, 15(8), 819-835.

Vallaster, C., \& de Chernatony, L. (2006). Internal brand building and structuration: The role of leadership. European Journal of Marketing, 40(7/8), 761-784.

Vandenberghe, C., \& Bentein, K. (2009). A closer look at the relationship between affective commitment to supervisors and organizations and turnover. Journal of Occupational \& Organizational Psychology, 82(2), 331-348.

Wasti, S. A. (2002). Affective and continuance commitment to the organization: Test of an integrated model in the Turkish context. International Journal of Intercultural Relations, 26(5), 525-550.

Wentzel, D., Henkel, S., \& Tomczak, T. (2010). Can I live up to that ad? Impact of implicit theories of ability on service employees' responses to advertising. Journal of Service Research, 13(2), 137152.

Westphal, A., \& Gmür, M. (2009). Organisationales Commitment und seine Einflussfaktoren: Eine qualitative Metaanalyse. Journal für Betriebswirtschaftslehre, 59(4), 201-229.

Wiener, Y. (1982). Commitment in Organizations: A Normative View. Academy of Management Review, 7(3), 418-428.

Wittke-Kothe, C. (2001). Interne Markenführung. Wiesbaden.

Xiong, L., King, C., \& Piehler, R. (2013). That's not my job: exploring the employee perspective in the development of brand ambassadors. International Journal of Hospitality Management, 35(12), 348-359.

Zeplin, S. (2006). Innengerichtetes identitätsbasiertes Markenmanagement. Wiesbaden. 